\title{
AN OVERVIEW ON THE BRAZILIAN ORANGE JUICE PRODUCTION CHAIN ${ }^{1}$
}

\author{
RENATO MARCIO DOS SANTOS², IRENILZA DE ALENCAR NÄÄS ${ }^{3}$, \\ MARIO MOLLO NETO ${ }^{4}$,ODUVALDO VENDRAMETTO 5
}

ABSTRACT - Brazil is the world's largest producer of oranges and uses more than $70 \%$ of the harvested fruits in the production of juices. The amount of processed orange is growing about $10 \%$ per year, confirming the trend of the Brazilian citrus for juice production. This research aimed to investigate the Brazilian orange juice production chain from 2005 to 2009. Data from the amount of frozen juice produced and exported, international price of orange juice, and intermediate transactions were assessed in order to make possible selection of all interveners involved in the chain. The study using the Social Network Analysis (SNA) showed that the densest relationships in the network are from exporters to importers and from orange growers to the orange processing industry. No difference was found in the values of the network geodesic distance or the clustering coefficients from 2005 to 2009 . The degree of centrality increased steadily throughout the years indicating that the processing industry attempts to minimize the risks by centralizing the actions. A decrease in export of orange juice from $2007\left(2.0710^{6} \mathrm{t}\right)$ to $2008\left(2.0510^{6} \mathrm{t}\right)$ was found, probably due to the world's financial crisis with recovery in 2009. Since 2004, there has been an increase of nearly $10 \%$ per year in the market preference of concentrate juice (OFCJ) when compared to the "not from concentrated" juice (NFC). Nowadays the NFC market represents nearly $50 \%$ of all Brazilian export which impacted in the logistic distribution and transportation issues.

Index terms: network analysis, SNA, production chain, orange production.

\section{UMA VISÃO DA PRODUÇÃO BRASILEIRA DE SUCO DE LARANJA}

RESUMO - O Brasil é o maior produtor de laranjas no mundo e utiliza mais de $70 \%$ das frutas que produz na fabricação de suco. A proporção de laranjas processadas vem crescendo cerca de $10 \%$ ao ano, confirmando a tendência da citricultura brasileira para a produção de suco. O objetivo deste trabalho foi apresentar uma visão geral sobre a cadeia de produção de suco de laranja brasileiro por meio da análise de rede social a partir de 2005 a 2009. Os dados de volume de suco congelado produzido e exportado, o preço internacional do suco de laranja e as transações intermediárias foram avaliados a fim de tornar possível a matriz de todos os intervenientes na cadeia. O estudo, utilizando a Análise de Redes Sociais (ARS) mostrou que as relações mais densas na rede são as de exportadores para importadores e produtores de laranja para a empresa de processamento. Não houve diferença nos valores da distância geodésica ou coeficientes de agrupamento da rede, de 2005 a 2009. O grau de centralidade aumentou de forma constante ao longo dos anos, indicando que a indústria de processamento tenta minimizar os riscos através da centralização das ações. A exportação de suco de laranja diminuiu de $2007\left(2,0710^{6} \mathrm{t}\right)$ para $2008\left(2,0510^{6} \mathrm{t}\right)$, provavelmente devido à crise financeira mundial, recuperando em 2009. Desde 2004, houve um aumento de quase $10 \%$ ao ano na preferência do mercado a partir do suco concentrado (OFCJ) para o "não concentrado" suco (NFC). Hoje, o mercado de NFC representa quase $50 \%$ de toda a exportação brasileira, o que impactou na distribuição logística e nas questões de transporte.

Termos para indexação: análise de redes, ARS, cadeia produtiva, produção de laranja.

\footnotetext{
'(Trabalho 252-12). Recebido em: Aceito para publicação em:

${ }^{2}$ MS em Engenharia de Produção - UNIP -São Paulo. renato10online@yahoo.com.br

${ }^{3} \mathrm{PhD}$ em Engenharia Agrícola. Prof. Titular. Graduate Program in Production Engineering, PPGEP/UNIP. Dr. Bacelar St. 1212, CEP 04026-002, São Paulo, Brazil.E-mail: irenilza@gmail.com

${ }^{4}$ Dr. em Engenharia Agrícola. Prof. Titular - PPGEP/UNIP. E-mail: mariomollo@gmail.com

${ }^{5}$ Dr. em Engenharia de Produção. Prof. Titular - PPGEP/UNIP. E-mail: oduvaldov@uol.com.br
} 


\section{INTRODUCTION}

Orange juice represents one of the main production chains in Brazil, corresponding to nearly 17.8 million tons produced yearly. Records during 2009 indicate a production of 1.0 million tons of orange juice, which is equivalent to $57 \%$ and $80 \%$ of the world's exports (DESER, 2009). Most orange juices are mechanically extracted and concentrated to reduce the cost of transportation and storage (CRANDALL et al, 1987; ARENA et al., 2006). The commercial processes of concentrating orange juice usually involves the removal of water at high temperature followed by recovery and concentration of volatile aromas, and their addition back to the concentrated product. However, most juice manufacturers do not restore all the original volatiles, probably for economic reasons (ARENA et al., 2006). Orange juice can be frozen and sold as frozen concentrated orange juice (FCOJ), or stored and shipped in bulk to a distant distribution point where dilution, reheating, and packaging occurs. The aroma of many RFC juices heated or processed, differ from that of freshly squeezed oranges (BRAT et al., 2003; ARENA et al., 2006). This off-odor is observed most commonly in canned RFC juices, which are heated twice, one during the concentration process and again after the juice is diluted with local water and hot filled to sterilize the container. These thermal treatments induce chemical changes in orange juices, which severely degrade the fresh orange juice volatiles, and produce new volatiles (SHAW et al., 1993).

The world's largest importers of orange juice are respectively, the United States, Canada, Japan, Russia and China (USDA, 2009). Increase in export requires constant efforts in logistics activities and processes of production, sustainability of the production network. Brazilian orange juice industry went through a period of crisis in the second semester of 2007, which was associated to the fall of prices of the commodity, and the decrease in the world's demand for the product. The cause was also related to the recovery of orchards in Florida, which Brazil is the biggest competitor, the additional cost of citrus production limiting the supply of juice due to higher incidence of diseases, and the growing loss of power of farmers who were facing the growing expansion of sugar cane plantations in the state of São Paulo (ABECITRUS, 2007). These are just some of the challenges that companies in this segment need to address to stay leader in the market at that time, and the scenario worsened with the global economic crisis in 2008.
The supply/production chain can be understood as a network that performs the search of material, transforms these materials into intermediate and finished products, and then distributes them to customers. Supply chain is defined as a network of organizations connected downstream and upstream with relations of cause and effect processes and activities; value is attached to the products and services delivered to the consumer (LEE; BILLINGTON, 1993; CHRISTOPHER, 2003). When applying strategic alliances, each company contributes to its core competencies and through the alliance may reach better results than each member alone has to offer, and can still get results that none company alone is capable of achieving (TICHY et al., 1979; CHURCHILL; PETER, 2000). Supply chain networks involve several linked actions between market segments and governmental bodies, which can be considered similar to a social network, and it may be considered within the principles of SNA. Initially developed to describe social structures, SNA has its origins in the studies of patterns of communication, influence and interactions within social groups (SCOTT, 2000; RICHARDSON, 2009). Furthermore, a method of drawing on graph theory was developed for describing and analyzing the relationships amongst members of a group with explicit links and interactions (CARPENTER; WESTPHAL, 2001).

This research aimed to analyze the orange juice supply chain, the interveners which compose it, and their interactions, in order to give an overview of the Brazilian production chain from 2005 to 2009 using the social network analysis.

\section{METHODOLOGY}

Data on volume of orange frozen juice produced, volume of frozen juice exported, the international price of orange juice and the intermediate transactions were assessed in several sources directly related to orange and frozen juice production in order to make possible to array of all interveners involved in the chain (Secretary of Foreign Commerce SECEX), Brazilian Association of Citrus Export - ABECITRUS, Brazilian Association of Citrus Producers - ASSOCITRUS, Department of Rural and Socio-Economic Studies-DESER, Syndicate of Frozen Food and Concentrated Industry in the State of São Paulo- SICONGEL, and the United States Department of Agriculture-USDA).

The orange juice network was represented by three basic elements: nodes or interveners, links and relationships, and flows of actions and information 
(Figure 1). The following actions were considered within the network: fruit production; storage of the fruit; transportation from the producer to the processing plant; processing of the fruit; storage at the processing plant; transportation from the processing plant to the export terminal, shipment of the product; and transportation to its destination.

Nodes or interveners are the people, groups of persons or companies acting within the network. Each intervener is a node. The size of the network is obtained by adding all nodes. This study considered the following interveners in the orange juice production chain: the grower of the fruit; the responsible for storage at the farm level; the responsible for transporting the fruit from the farm to the processing plant; processing of the fruit; the responsible for storage at the processing plant; the responsible for transportation from the processing plant to the export terminal, the responsible for the handling and shipment of the juice; and the responsible for transportation to its final destination. Here, the responsible was not necessarily a person, but a segment of the company.

The intermediate nodes were the governmental regulatory agencies (Brazilian Health Agency ANVISA; Ministry of Agriculture - MAPA; Federal Police) and private auditing agencies (Regulatory agency; GLOBALGAP). Link is the tie between two or more nodes, which is represented by a straight line. The links adopted here were all connections between the orange juice supply chain interveners. The flow indicates the direction of the action between the interveners. Here, there were taken into account the flow of products, services and the payments involved in the identified interactions (Table 1). Data from 2005 to 2009 were organized showing the relationships between the interveners.

The values of the following network structural properties were compared: 1) density (the ratio of all ties that are actually present to the number of possible ties); 2) degree of centrality (which refers to the amount of immediate ties the intervener has within the network, \%);3) clustering coefficient (which refers to the average of the densities of the neighborhoods of all interveners; 4) node (which is the same as element or intervener); and 5) geodesic distance (which is the length of the shortest path between the interveners). The higher the weight is given to the relationship the better the interaction is between interveners and the data flow is more reliable within the network/chain (HANNEMAN; RIDDLE, 2005).

The analysis was carried out using the UCINET ${ }^{\circledR} 6$ for Windows ${ }^{\circledR}$ software tool (UCINET,
2002; BORGATTI; LI, 2009) with the goal to survey the interactions, to identify the interveners rules and their graphical structure; and to indicate how the network chain is built. In this research, the structural measurements of network centrality, the identification of network subgroups, and analysis of roles were done using the theory of graphs in the UCINET $^{\circledR}$ software integrated module NETDRAW ${ }^{\circledR}$, which also enabled visualization of the network graph data.

\section{RESULTS AND DISCUSSION}

From the interactions between the interveners during all studied years it was found that the most powerful links are those connecting the exporter to the importer and the orange grower to the orange processor, represented in Figure 2. Some interactions overlapped generating a thicker line between the interveners and indicating the increase in density; and, therefore, making that link strategically more valuable. The numbers shown are the monetary values of the transactions, and the volume of juice processed and transported. It is also enhanced the role of the government which concentrates most of the actions that in this case are related to taxations and auditing. There are several ways to represent the network flow for the cash management, cash flow in the food industry, and the interactions found in this research present the same array as those found by previous authors (AHUMADA; VILLALOBOS, 2009; PACHECO; MORABITO, 2011).

The visual analysis indicates that the networks did not present significant changes in their arrangement throughout the studied years. The slight changes are perceived in the most relevant links of three interveners, orange grower, importer, and processing unit. Further strengthening appears in the relationship between the importer and exporter and, in second importance between the orange grower and the juice producer. The most influential nodes during the studied period are those shown in Table 2.

Average distances were maintained relatively constant in the period, and no change in the clustering coefficient was found (Table 3), indicating that the network remained stable despite changes in the market. This is probably a result of the quota system adopted by importing/exporting countries (NEVES et al., 2001).

Density values (10.4 to 11.9$)$ presented steady increase from 2005 to 2008 , indicating an escalation in the network interveners' organization and creating a cohesive structure. In 2009, the network undergoes a decline in its organization. 
This generally occurs due to an external factor, and in this case, it was probably the consequence of the 2008 economic crisis. The relative inertia found in the network density from 2005 to 2008 probably led to rearrangement of power. The orange grower, although producing the basic commodity, is the third intervener in importance, in the network.

From the studied network parameters, only the density and the degree of centrality presented changes (Figure 3). The degree of centrality, which refers to the amount of immediate ties the intervener has within the network presented an increase from the year of $2005(10.4 \%)$ until $2008(11.9 \%)$, while the homogeneity in the relationships between interveners remained relatively constant, slightly decreasing on $2009(11.7 \%$ ), again probably as a result of the world economic crisis.

When the density is high, the strength of the network ties is good, denoting that more information is exchanged from the interveners, which usually means worthy data flow (WASSERMAN; FAUST, 1994). The clustering coefficient (Equation 1) was defined as:

$$
\mathrm{C}_{\mathrm{i}}=2 \mathrm{n} / \mathrm{k}_{\mathrm{i}}\left(\mathrm{k}_{\mathrm{i}}-1\right)
$$

where $n$ represents the number of direct links connecting the $\mathrm{k}_{\mathrm{i}}$ nearest intervener of node $\mathrm{i}_{\mathrm{i}}$; it is equal to 1 for a node at the center of a fully interlinked cluster, and it is equal to 0 for an intervener that is part of a loosely connected group. Therefore, $\mathrm{C}_{\mathrm{i}}$, the average over all nodes $s_{i}$ of a network, is a measure of the network's potential modularity.

\section{Orange juice production trend}

Another information from the studied data was the decrease in export of frozen juice from 2007 (2.07 $10^{6}$ ton) to 2008 (2.05 $10^{6}$ ton) overlapping with the beginning of the global financial crisis (Figure 4). In 2009 , the orange juice industry presented a recovery exporting 2.10 million ton. In order to maintain trust and reduce the risk, companies in charge of the actions such as transportation and production either merged or were bought, resulting in a large company that practically own all segments of the process (NEVES et al., 2001). This agrees with CHURCHILL; PETER (2000) who support the need of strategic alliances for technology sharing in the developing of companies. When not relying in their suppliers, companies choose to concentrate their actions and reduce their eventual threat with merging actions (CHURCHILL; PETER, 2000; CHRISTOPHER, 2003).
Worldwide the supply chain of food products are currently under public debate, and better informed consumers need to ensure products quality. This movement is usually followed by additional regulations and market driven standards that will affect the performance of a complex supply chain. This difficulty is upraised when the supply chain encompasses international trade (AHUMADA; VILLALOBOS, 2009). Thus, the concentration of actions and management of some interveners within the supply chain might seem to determine the best strategies to accommodate the new global market conditions (BERCK et al., 2008; ABEBE et al., 2010; LEE et al., 2010).

As the demand for higher quality orange juice has increased, studies have been undertaken to identify flavor changes produced in the preparation of various juice types and how to avoid or minimize them (ARENA et al., 2006; PEREZ-CACHO; ROUSEFF, 2008). Selected volatiles from pasteurized, not from concentrate, NFC, orange juices were not noticeably different from those of fresh juice. Freshly extracted and commercial unpasteurized juices contain larger amounts of volatile aroma compounds than RFC (twice heated) juices, which may compromise quality. For instance, fresh unpasteurized juice contained 11 to 53 times more acetaldehyde than the RFC juices (PEREZ-CACHO; ROUSEFF, 2008).

From the studied data, it was also possible to identify a new trend in export. Since 2004, there has been a significant increase in the preference of market from the OFCJ to the NFC (not from concentrated), and nowadays the NFC market represents nearly $50 \%$ of all Brazilian export (Figure 4). As it is more economical to ship a concentrated juice and add water at the destination, than shipping juice with all its natural water content, the export of orange juice implied in more structural investments. Within this new scenario, it is clear that Brazil is increasing the export of water in the orange juice, which upsurges the logistic distribution and transportation. 
TABLE 1- Interactions between interveners within the network that describes the simplified Brazilian supply chain of orange juice.

\begin{tabular}{ccc}
\hline From & To & Number of interactions \\
\hline Orange producer & Orange transportation & 1 \\
Orange producer & Local government & 2 \\
Orange producer & Federal government & 2 \\
Orange transportation & Processing industry & 2 \\
Orange transportation & Local government & 2 \\
Orange transportation & Fuel & 2 \\
Electrical energy & Federal government & 1 \\
Juice transportation & Fuel & 2 \\
Electrical energy & Processing industry & 2 \\
Water supply & Processing industry & 2 \\
Processing industry & Juice transportation & 1 \\
Water supply & Federal government & 1 \\
Juice transportation & Export warehouse & 2 \\
Export warehouse & Regulatory agency & 2 \\
Regulatory agency & Federal government & 1 \\
Export warehouse & Export market & 2 \\
Water supply & Export warehouse & 2 \\
Total of interactions & & $\mathbf{2 9}$ \\
\hline
\end{tabular}

TABLE 2 - Classification of the interveners' importance within the orange juice network from 2005 to 2009.

\begin{tabular}{cccccc}
\hline Year & $1^{\text {st }}$ intervener & $2^{\text {nd }}$ intervener & $3^{\text {rd }}$ intervener & $4^{\text {th }}$ intervener & $5^{\text {th }}$ intervener \\
\hline $2005-2009$ & Juice exporter & Government & Orange grower & Juice carrier & Importer \\
\hline
\end{tabular}

TABLE 3- Summary of network output data from 2005 to 2009

\begin{tabular}{ccccc}
\hline Year & Geodesic distance & Density $\left(10^{6}\right)$ & Clustering coefficient $\left(10^{6}\right)$ & Degree of centrality (\%) \\
\hline 2005 & 2.1 & 25.7 & 8.6 & 10.4 \\
2006 & 2.1 & 29.9 & 8.6 & 11.0 \\
2007 & 2.1 & 40.3 & 8.6 & 11.5 \\
2008 & 2.1 & 35.7 & 8.6 & 11.9 \\
2009 & 2.1 & 32.0 & 8.6 & 11.7 \\
\hline
\end{tabular}

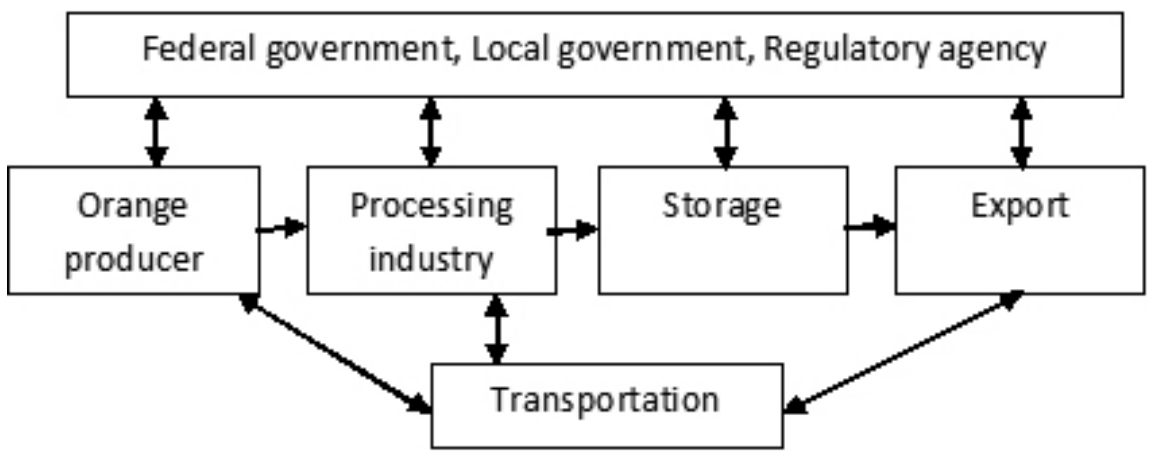

FIGURE 1- Basic structural scheme of the orange juice network interveners and actions. 


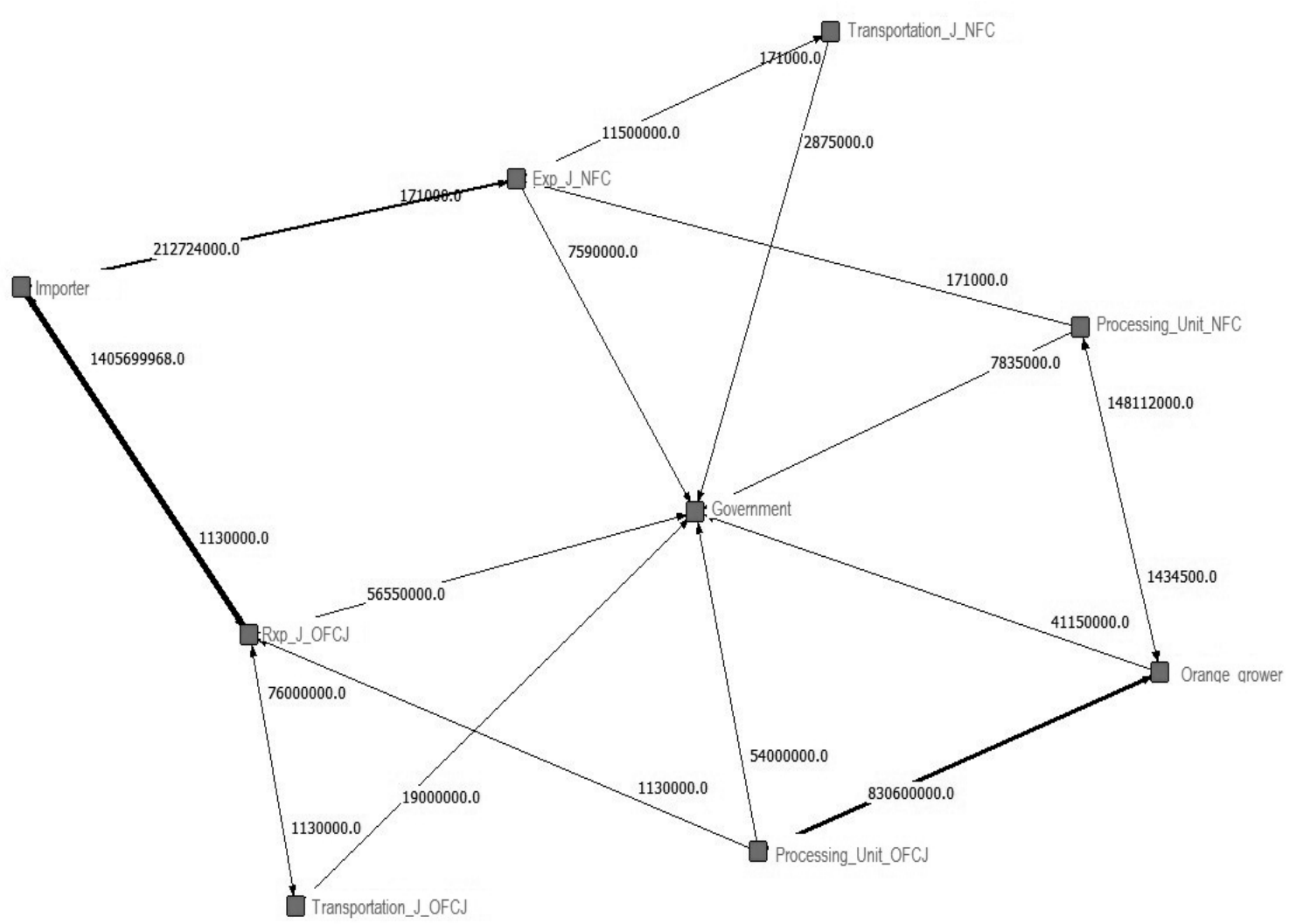

FIGURE 2 - NETDRAW ${ }^{\prime}$ ' structural drawing output of the Brazilian orange juice network in the year 2009.

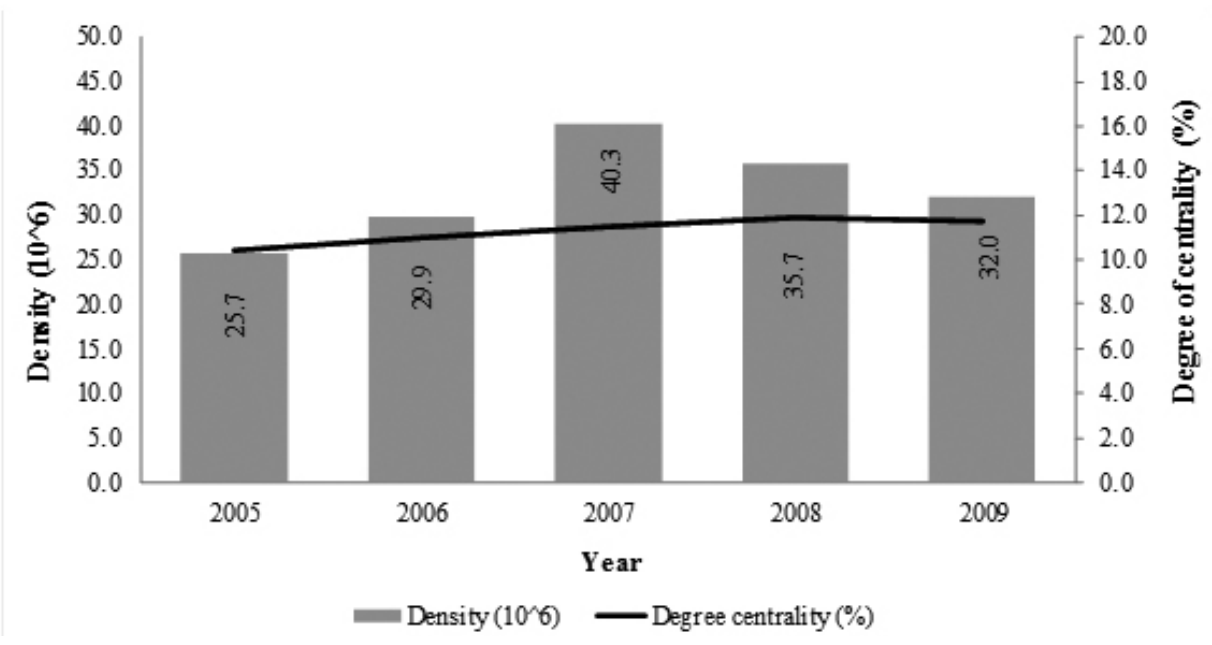

FIGURE 3- Network parameters of density and centrality of the interveners' relationships in the orange juice production chain from 2005 to 2009 . 


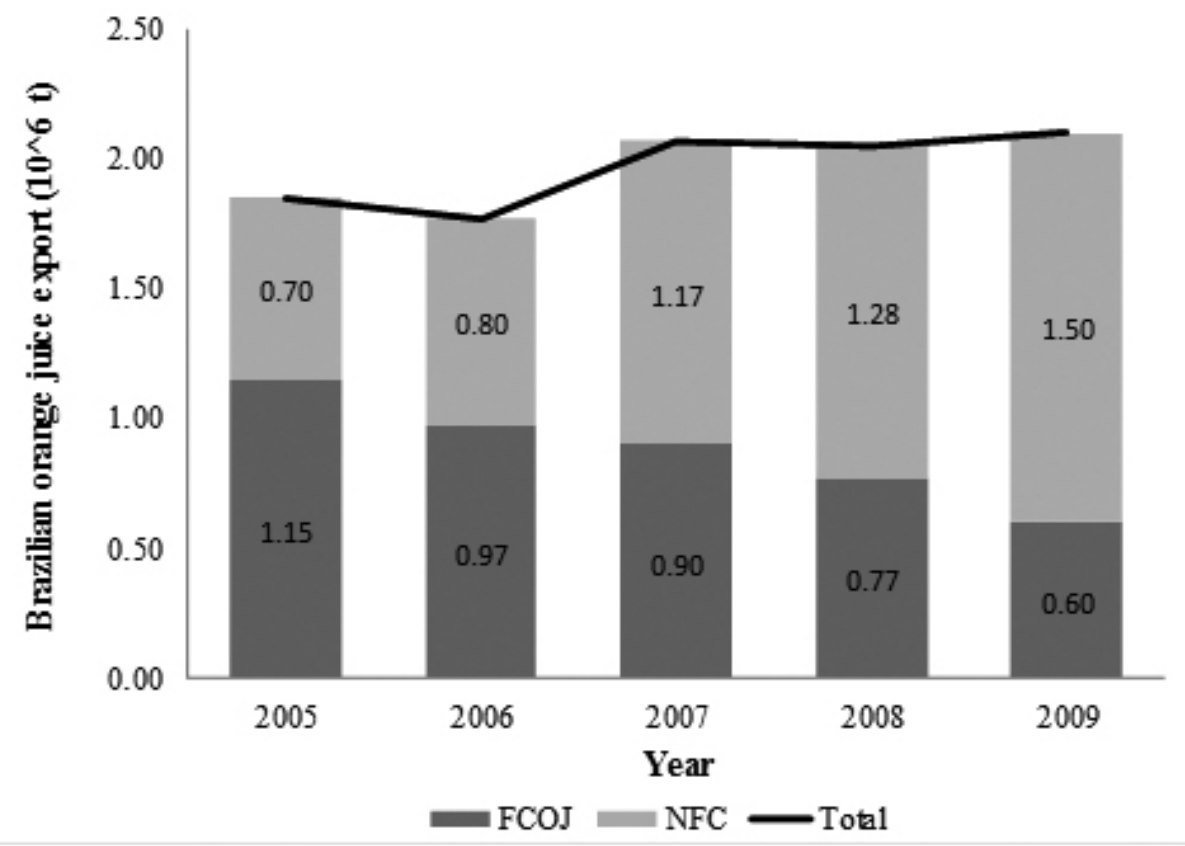

FIGURE 4 - Brazilian orange juice concentrated (FCOJ) and fresh (NFC) export data from 2005 to 2009. Adapted from (ABECITRUS,2007).

\section{CONCLUSIONS}

When analyzing the orange juice production chain, the interveners, which seemed to be independent business partners were, in fact, highly compromised with the processing industry. Although the network shows distinct interveners interfacing from the fruit production to the export companies, most of them are directly connected to the processing company transforming the chain into a business vertical structure. Since 2004, there has been an increase of nearly $10 \%$ per year in the market preference from the concentrate juice (OFCJ) to the "not from concentrated" juice (NFC), and nowadays the NFC market represents nearly $50 \%$ of all Brazilian export which impacted in the logistic distribution and transportation issues.

\section{REFERENCES}

ABEBE, M.; ANGRIAWAN, A.; TRAN, H. Chief executive external network ties and environmental scanning activities: an empirical examination. Strategic Management Review, Dallas, v. 4, n. 1, p. 30-43, 2010.

ABECITRUS - Associação Brasileira dos Exportadores de sucos cítricos. Relatório Abecitrus 2007. Disponível em: <http//www.abecitrus.com.br $>$. Acesso em: 15 dec. 2010.

ARENA, E. et al. Comparison of odour active compounds detected by gas-chromatography-olfactometry between hand-squeezed juices from different orange varieties. Food Chemistry, Amsterdam, v. 98, n.1, p.59-63, 2006.

AHUMADA, O.; VILLALOBOS, J.R. Application of planning models in the agri-food supply chain: A review. European Journal of Operational Research, Amsterdam, v. 196, n. 1, p. 1-20, 2009.

BERCK, P.; BROWN, J.; PERLOFF, J.M.; VILLASBOAS, S.B. SALES: Tests of theories on causality and timing. International Journal of Industrial Organization, Amsterdam, v. 26, n. 6, p. 1257-1273, 2008 . 
BORGATTI, S.P.; LI, X. On social network analysis in a supply chain context. Journal of Supply Chain Management,Temple, v. 45, n. 2, p. 5-22, 2009.

BRAT, P. et al. Distribution of volatile compounds in the pulp, cloud, and serum of freshly squeezed orange juice. Journal of Agricultural and Food Chemistry, Columbus, v.51, n.11, p.3442-3447, 2003.

CARPENTER, M.A.; WESTPHAL, J.D. The strategic context of external network ties: Examining the impact of board appointments on director involvement in strategic decision making. Academy of Management Journal, New York, v.44, n. 2, p. 639-660, 2001.

CHRISTOPHER, M. Logística e gerenciamento da cadeia de suprimentos: Estratégia para redução de custos e melhoria dos serviços. São Paulo: Pioneira, 2003. 488p.

CHURCHILL, G.A.J.R.; PETER, J.P. Marketing: criando valor para os clientes. 2. ed. São Paulo: Saraiva, 2000. 626p.

CRANDALL, P.G.; CHEN, C.S.; DAVIS, K.C. Preparation and storage of $72^{\circ}$ Brix orange juice concentrate. Journal of Food Science, Chicago, v.52, n. 2, p. 381-385, 1987.

DESER - Departamento de Estudos Sócio-Econômicos e Rurais. A cadeia produtiva da laranja - estudos exploratórios. Curitiba. 2007. Disponível em: $<$ http://www.deser.org.br/pub_read.asp?id=112>. Acesso em: 12 dez. 2011.

HANNEMAN R.; RIDDLE M. Introduction to social network methods. 2005. Disponível em: http://faculty.ucr.edu/ hanneman/nettext/introduction_to_social_network_methods.pdf. Acesso em: 3 mar. 2010.

LEE, H.L.; BILLINGTON, C. Material management in decentralized supply chain. Operational Research, New York, v.41, n.5, p. 835-847, 1993.

LEE, J-Y.; GAO, Z.; BROWN, M.G. A study of the impact of package changes on orange juice demand. Journal of Retailing and Consumer Services, Amsterdam, v.17, n. 6, p. 487-491, 2010.
NEVES, E. M. et al. Citricultura brasileira: efeitos econômico-financeiros, 1996 - 2000. Revista Brasileira de Fruticultura, Jaboticabal, v.23, n.2, p. 432-436, 2001.

PACHECO, J.V.A.; MORABITO, R. Application of network flow models for the cash management of an agribusiness company. Computers \& Industrial Engineering, Amsterdam, v. 61, n. 3, p. 848-857, 2011.

PEREZ-CACHO, P.R., ROUSEFF, R. Processing and storage effects on orange juice aroma: A review. Journal of Agricultural and Food Chemistry, Columbus, v.56, n. 21, p. 9785-9796, 2008.

RICHARDSON, A.J. Regulatory networks for accounting and auditing standards: A social network analysis of Canadian and international standardsetting. Accounting, Organizations and Society, Amsterdam, v. 34, n. 5, p. 571-588, 2009.

SCOTT, J. Social network analysis: A handbook. 2.ed. London: Sage Publications, 2000. 208p.

SHAW, P.E.; BUSLIG, B.S.; MOSHONAS, M.G. Classification of commercial orange juice types by pattern recognition involving volatile constituents quantified by gas chromatography. Journal of Agricultural and Food Chemistry, Columbus, v. 41, n. 5 , p. $809-813,1993$.

TICHY, N.M.; TUSHMAN, M.L.; FOMBRUN, C. Social network analysis for organizations. Academy of Management Journal, New York, v. 4, n. 2, p.507-519, 1979.

UCINET. Ucinet 6 for Windows: software for social network analysis. Massachusetts: Analytic Technologies, 2002.

USDA - United States Department of Agriculture. USDA Report 2009. Disponível em: $\leq \mathrm{http}: / / \mathrm{www}$. fas.usda.gov/htp/2009 Citrus.pdf $>$. Acesso em: 20 dec. 2010.

WASSERMAN, S.; FAUST, K. Social Analysis network. Cambridge: Cambridge University Press, 1994. $825 \mathrm{p}$. 